\title{
Certificated sickness absence in industrial employees threatened with redundancy
}

\author{
NORMAN BEALE, SUSAN NETHERCOTT
}

\begin{abstract}
The proposition that workers take less sick leave when threatened by redundancy was examined in a longitudinal, controlled study using information from case records in a general practice. The hypothesis was only partly supported-certificated sickness absence dropped only in employees under the age of 40. Workers fearing job loss reported more illness, and their periods of absence were significantly longer, especially for men and for workers who had previously consulted their general practitioner infrequently.

This study provides further evidence that the fear of mass redundancy is stressful to workers so threatened and costly to a society experiencing rising unemployment.
\end{abstract}

\section{Introduction}

For much short term illness patients themselves decide not to go to work, ${ }^{12}$ visiting the doctor only to obtain authorisation for the absence from work - the motive for a quarter of consultations by those aged 16 to $65 . .^{34}$

Rates of certification of sickness absence vary throughout Britain ${ }^{5}$ and are lower in smaller firms ${ }^{6}$ and in shift workers than in day workers. ${ }^{7}$ Job satisfaction and social and financial factors must be pertinent to taking sick leave. ${ }^{6}$ It is also supposed that workers become increasingly reluctant to take sick leave if unemployment rates rise, ${ }^{810}$ but this assertion remains untested at the end of a

Health Centre, Calne, Wiltshire SN11 8NQ

NORMAN BEALE, MA, MRCGP, general practitioner

SUSAN NETHERCOTT, MSC, statistician

Correspondence to: Dr Beale. decade which has seen a threefold rise in the national unemployment rate. One small study found that sick leave rose in railwaymen threatened with redundancy, but job vacancies were then plentiful. ${ }^{1}$

The system of registering patients with general practitioners in Britain places these doctors in a favourable position to undertake research of the "before/after" type that would show the relation of absence due to illness to threatened redundancy. Such an opportunity arose when C \& T Harris (Calne) Ltd, the main employer in a small town in Wiltshire was forced to make staged redundancies. Some findings have already been reported. ${ }^{12-15}$ In this study we test the hypothesis that industrial workers who know they are threatened with redundancy take less certificated sickness absence than they did during an earlier, secure, period of employment.

\section{Method}

After a mass redundancy at C \& T Harris in mid-1980 the remaining workforce learned that the plant might ultimately be closed, and this happened in July 1982 . The study group consisted of all process and clerical workers who lost their jobs when the factory closed and who $(a)$ were men aged 60 or less or women aged 55 or less; $(b)$ had been full time employees for six years or more; and $(c)$ had been registered as patients at Calne health centre for six years or more.

The control group consisted of all workers in other industries in Calne who fulfilled the age, employment, and registration criteria and who remained in employment for the six years of the study period.

The following information was obtained from the records of the practice: (a) number of episodes of illness reported by workers in the "jobs secure" period (1 July 1976 to 30 June 1980) and in the "jobs insecure" period (1 July 1980 to 30 June 1982); (b) incidence of certificated episodes-the proportion of certificated episodes (issue of a form Med 3 or Med 5) to the total reported episodes in each period; $(c)$ duration of certificated episodes-the number of calendar days (customarily used rather than working days) authorised for each certificated episode: (d) diagnostic category of certificated episodesusing the broad categories of the most recent disease classification intended for use in general practice. ${ }^{16}$ These measures were compared in the study and control groups for the secure and insecure periods of employment. Similar 
analyses were performed in cohorts subdivided by factors shown to be influential in the context of threatened job loss and health ${ }^{12}{ }^{13}$ : sex, age, and morbidity. Subjects were divided into those in the first and second halves of their working lives - that is, men above and below 40 and women above and below 35, and their morbidity was classed as high or low according to their consultation rate during the period of secure employment (above or below the mean consultation rate).

The Wilcoxon signed rank test was used to test for differences in the number of episodes of illness reported per patient in the secure period compared with the insecure period, and $95 \%$ confidence intervals were obtained for the differences in incidence of certificated episodes. ${ }^{17} \mathrm{Log}$ linear analyses were performed to rule out the possibility that differences in incidence of episodes of illness and episodes requiring certificates were invalidated by the confounding effects of age, sex, marital status, and job tenure. $^{18}$

The Mann-Whitney $U$ test was used to test unpaired data for differences in duration of certificated episodes between the secure and insecure periods.

\section{Results}

The group threatened with redundancy and the control group were closely matched in their use of health services while both were in secure

TABLE I-Characteristics of workers faced with redundancy at $C \mathcal{E} T$ T Harris (Calne) Ltd and workers securely employed elsewhere in Calne

\begin{tabular}{|c|c|c|c|c|c|}
\hline & Men & Women & $\begin{array}{c}\text { Median age } \\
\text { (years; } \\
\text { interquartile range) }\end{array}$ & $\underset{(\%)}{\text { Married }}$ & $\begin{array}{l}\text { Median job tenure } \\
\quad \text { (years; } \\
\text { interquartile range) }\end{array}$ \\
\hline \multicolumn{6}{|c|}{ All employees } \\
\hline Harris & 80 & 49 & $43(37-51)$ & 81 & $13(10-20)$ \\
\hline Control & 77 & 22 & $40(31-49)$ & 87 & $13(9-16)$ \\
\hline \multicolumn{6}{|c|}{ Male employees } \\
\hline Harris & 80 & - & $41(38-54)$ & 90 & $14(10-23)$ \\
\hline Control & 77 & - & $40(31-50)$ & 88 & $13(9-17)$ \\
\hline \multicolumn{6}{|c|}{ Female employees } \\
\hline Harris & - & 49 & $43(30-50)$ & 67 & $12(8-17)$ \\
\hline \multirow{2}{*}{\multicolumn{6}{|c|}{$\begin{array}{l}\text { Control } \\
\text { Older employees }\end{array}$}} \\
\hline & & & & & \\
\hline Harris & 43 & 35 & $51(44-54)$ & 91 & $17(10-26)$ \\
\hline Control & 34 & 17 & $49(45-53)$ & 90 & $13(11-16)$ \\
\hline \multicolumn{6}{|c|}{ Younger employees } \\
\hline Harris & 37 & 14 & $35(26-39)$ & 86 & $12(7-19)$ \\
\hline Control & 43 & 5 & $31(29-37)$ & 75 & $10(8-16)$ \\
\hline \multicolumn{6}{|c|}{ High consulters $†$} \\
\hline Harris & 33 & 17 & $41(36-53)$ & 86 & $12(8-21)$ \\
\hline & 28 & 8 & $38(30-50)$ & 81 & $11(8-16)$ \\
\hline \multicolumn{6}{|c|}{ Low consulters $\dagger$} \\
\hline Harris & 47 & 32 & $43(36-51)$ & 87 & $13(10-21)$ \\
\hline Control & 49 & 14 & $42(37-49)$ & 83 & $13(9-17)$ \\
\hline
\end{tabular}

${ }^{\star}$ Above/below 40 for men, 35 for women.

tConsulting the doctor more/less than the mean.

TABLE II-Incidence of episodes of illness requiring certificates

\begin{tabular}{|c|c|c|c|}
\hline & \multicolumn{2}{|c|}{$\begin{array}{l}\text { Proportion of episodes } \\
\text { requiring certificates: }\end{array}$} & \multirow[b]{2}{*}{$\begin{array}{l}\text { Difference in proportions } \\
(95 \% \text { confidence intervals })\end{array}$} \\
\hline & $\begin{array}{l}1 \text { July } 1976- \\
30 \text { June } 1980\end{array}$ & $\begin{array}{l}1 \text { July } 1980- \\
30 \text { June } 1982\end{array}$ & \\
\hline \multicolumn{4}{|c|}{ All employees } \\
\hline Harris & $0 \cdot 27$ & $0 \cdot 24$ & $0.03(-0.03$ to +0.09$)$ \\
\hline Control & $0 \cdot 28$ & $0 \cdot 28$ & $0 \quad(-0.07$ to +0.07$)$ \\
\hline \multicolumn{4}{|c|}{ Male employees } \\
\hline Harris & $0 \cdot 28$ & $0 \cdot 24$ & $0.04(-0.04$ to +0.12$)$ \\
\hline Control & 0.34 & 0.33 & $0.01(-0.08$ to +0.08$)$ \\
\hline \multicolumn{4}{|c|}{ Female employees } \\
\hline Harris & $0 \cdot 26$ & $0 \cdot 23$ & $0.03(-0.05$ to +0.11$)$ \\
\hline Control & $0 \cdot 15$ & $0 \cdot 17$ & $0.02(-0.10$ to +0.10$)$ \\
\hline \multicolumn{4}{|c|}{ Older employees $\dagger$} \\
\hline Harris & $0 \cdot 25$ & $0 \cdot 28$ & $0.03(-0.04$ to +0.10$)$ \\
\hline Control & $0 \cdot 27$ & $0 \cdot 25$ & $0.02(-0.07$ to +0.11$)$ \\
\hline \multicolumn{4}{|c|}{ Younger employeest } \\
\hline Harris & $0 \cdot 33$ & $0 \cdot 14$ & $0.19(+0.10 \text { to }+0.28)^{\star}$ \\
\hline Control & $0 \cdot 30$ & 0.33 & $0.03(-0.08$ to +0.14$)$ \\
\hline \multicolumn{4}{|c|}{ High consulters $\$$} \\
\hline Harris & 0.27 & 0.23 & $0.04(-0.03$ to +0.11$)$ \\
\hline Control & $0 \cdot 29$ & 0.36 & $0.07(-0.02$ to +0.16$)$ \\
\hline \multicolumn{4}{|c|}{ Low consulters $\S$} \\
\hline Harris & $0 \cdot 28$ & $0 \cdot 24$ & $0.04(-0.05$ to +0.13$)$ \\
\hline Control & $0 \cdot 27$ & $0 \cdot 16$ & $0.11(+0.01 \text { to }+0.21)^{\star}$ \\
\hline
\end{tabular}

${ }^{\star} \mathrm{p}<0.05$

†Above/below 40 for men, 35 for women.

CConsulting the doctor more/less than the mean July 1976-June 1980 employment (table 1)..$^{121315}$ Similarly, the proportions of episodes of illness needing certificates during the period of secure employment were comparable in most subgroups (table II). There were, however, significant decreases in the incidence of episodes needing certificates in two subgroups when the periods of secure and insecure employment were compared. The greater change, which might have been a consequence of threatened job loss, was in the company's younger employees. Periods of absence due to sickness were significantly longer in Harris employees when they faced redundancy, particularly for men and for those with a previously low consultation rate (table III).

TABLE III-Changes in incidence of episodes, duration of certificated episodes, or both

\begin{tabular}{|c|c|c|c|c|}
\hline & \multicolumn{2}{|c|}{ Episodes per patient per year } & \multicolumn{2}{|c|}{$\begin{array}{l}\text { Median duration (days) of } \\
\text { certificates issued } \\
(95 \% \text { confidence intervals) }\end{array}$} \\
\hline & Harris & Control & Harris & Control \\
\hline \multicolumn{5}{|l|}{ All employees: } \\
\hline Jobs secure & $1 \cdot 27$ & $1 \cdot 48$ & $9(7$ to 10$)$ & $7(7$ to 11$)$ \\
\hline Jobs insecure & $1 \cdot 40$ & $1 \cdot 28$ & $13(10 \text { to } 14)^{\star}$ & $8(7$ to 13$)$ \\
\hline \multicolumn{5}{|l|}{ Male employees: } \\
\hline Jobs secure & $1 \cdot 11$ & $1 \cdot 36$ & $8(7$ to 10$)$ & $9(7$ to 13$)$ \\
\hline Jobs insecure & $1 \cdot 18$ & $1 \cdot 15$ & $14(10 \text { to } 18)^{\star \star \star}$ & $7(6$ to 11$)$ \\
\hline \multicolumn{5}{|l|}{ Low consulters: } \\
\hline Jobs secure & $0 \cdot 68$ & 0.78 & $7(7$ to 11$)$ & $7(7$ to 9$)$ \\
\hline Jobs insecure & $1.09+$ & 0.75 & $14(9 \text { to } 18)^{\star}$ & 7 (7 to 14$)$ \\
\hline
\end{tabular}

${ }^{\star} \mathrm{p} \leqslant 0 \cdot 05 ;{ }^{\star \star} \mathrm{p} \leqslant 0 \cdot 001$, Mann-Whitney U test.

$t p \leqslant 0 \cdot 01$, Wilcoxon Signed Rank test.

The log linear analyses confirmed that employer (Harris $v$ controls) and previous use of health services (high or low consulting rate) significantly affected the incidence of episodes of illness and of episodes requiring certificates when jobs were insecure. The other variables (age, sex, job tenure, and marital status) had no significant effects and there were no significant interactions between them.

The significant increase in episodes of illness in relation to threatened redundancy seen in the Harris employees with a previously low consultation rate reinforces an earlier finding. ${ }^{13}$ Eliminating certificates given for absences of less than three days did not alter any of the findings. There was no indication of any change in the types of illness for which certificates were issued between the two periods.

\section{Discussion}

Adopting the sick role can be an escape from conflict or stress, and our results suggest that workers, particularly men, take longer spells of sick leave when facing mass redundancy. They seek medical advice more often (especially if they have seen their doctor infrequently when their jobs were secure) and take longer to overcome the symptoms which keep them at home. The popular supposition that workers under threat of losing their jobs will take less sick leave is supported only by the behaviour of workers under 40 years old. Perhaps, being younger, they have more to fear from the "last hired, first fired" principle and think that a poor attendance record might make them more likely to be among the first to lose jobs.

Personnel managers are well aware that the threat of mass redundancy is stressful to all concerned, but they should not assume that such a fear will promote better attendance in the workforce. If, as in this study, the degree of apprehension results in increasing absenteeism then this may compound the problems facing the management. The general practitioner or the occupational physician should remember to refer to fear of unemployment if employees seem reluctant to return to work after illnesses which they might previously have shrugged off.

Medical certificates cost the taxpayer, directly and indirectly, as much as does the health service, ${ }^{1}$ and absence due to illness has caused the loss of more working days than have industrial disputes. ${ }^{5}$ Our findings indicate a further loss of industrial efficiency from increased sick leave before redundancy. The real price of unemployment may therefore include the sick pay claimed by those who still have a job but now have reduced job security and satisfaction. Rather than having a salutary effect on a self indulgent minority, the 
spectre of redundancy seems to tax the loyalty even of committed workers-a costly and disruptive outcome.

We thank our families for tolerating our "absences"; the staff at Calne health centre; Miss K Clarke of the medical library, Postgraduate Centre, Royal United Hospital, Bath; Mr P Carr for use of the facilities at Bath University Computing Services; and Dr Paul Christie for help with computer analyses. We also thank the scientific foundation board of the Royal College of General Practitioners for continuing financial support and Dr Ian Russell for his advice.

\section{References}

1 Anonymous. Sickness absence. Br Med f 1974;iv:249.

2 Grossmark F, Sharer P. A study of certification in general practice. Practitioner 1976;199:354-5.

3 Carne S. Sick absence certification: analysis of one practice in 1967. Br Med F 1969;1:147-9.

4 Lunn J, Rider J, Waters W, Charnock R. Certification of unfitness for work. I R Coll Gen Pract 1970;19:215-22.
5 Haines A. Sickness absence. $f(R$ Coll Gen Pract 1982:32:396-400.

6 Taylor P. Sickness absence: facts and misconceptions. $\mathcal{I} R$ Coll Physicians Lond 1974;8:315-33.

7 Anonymous. Facts and myths about sickness absence. Lancet 1974;ii: 706.

8 Taylor P, Pocock S. Post-war trends in sickness absence and unemployment in Great Britain. Lancet 1969;ii:1120-3.

9 Tanner C. Unemployment in my practice-South Shields. Br Med $\mathcal{F} 1981 ; 283: 201-2$

10 Higgs R. Unemployment in my practice-Walworth, London. BrMed J 1981;238:532.

11 Owens C. Sick leave among railwaymen threatened by redundancy: a pilot study. Occupational Psychology 1966;40:43-52

12 Beale N, Nethercott S. Job-loss and family morbidity: a study of a factory closure. $7 R$ Coll Gen Pract 1985;35:510-4.

13 Beale $\mathrm{N}$, Nethercott $\mathrm{S}$. Job-loss and health-the influence of age and previous morbidity. $\mathcal{f} R \mathrm{Coll}$ Gen Pract 1986;36:261-4.

14 Beale N, Nethercott S. Job-loss and morbidity: the influence of job-tenure and previous work history. F R Coll Gen Pract 1986;36:560-3.

15 Beale N, Nethercott $S$. The health of industrial employees four years after compulsory redundancy. I R Coll Gen Pract 1987;37:390-4.

16 Royal College of General Practitioners. Classification of diseases, problems and procedures 1984 London: Royal College of General Practitioners, 1984.

17 Diem K, ed. Documenta Geigy scientific tables. Manchester: Geigy Pharmaceutical Co, 1962.

18 Baker R, Nelder J. The GLIM system manual. Oxford: Numerical Algorithms Group, 1978.

(Accepted 9 February 1988)

\section{ONE HUNDRED YEARS AGO}

The Queen has often shown her keen sympathy with the poorer citizens of this country when some great calamity has shocked the public mind; and in the manner in which she has decided to dispose of the surplus of the Women's Jubilee Offering she gives evidence of her helpful sympathy with the industrial classes in those domestic calamities, less extensive indeed, but in their incidence on the individual not less severe, which are the common lot of every household. Such calamities, while they do not spare, as the Queen has so often sadly experienced, the most elevated social situations, bear with peculiar hardness on the classes in which health and the power to work are their only wealth.

The Queen has taken counsel of experienced counsellors, and has been wisely advised. She has approved the recommendation of the Duke of Westminster, Sir James Paget, and Sir Rutherford Alcock that the surplus of the Women's Jubilee Offering, which was a personal present to the Queen herself, should be devoted to the foundation of an institution for promoting the education and maintenance of nurses for the sick poor in their own homes. Guarded by reasonable safeguards against abuse, such a system of home nursing is calculated to confer enormous and as yet inestimable benefits upon the artisan class. The scheme is merely sketched in the letter which we publish in another column, but its general scope may be well perceived. It is none the less likely to be popular and useful because it does not betray a disposition to seek novelty for novelty's sake. The plan has been tried on a fairly extensive scale in several districts of London, and in certain provincial towns, and has been found to work on the whole most satisfactorily.

The value of good nursing in the treatment of serious illness is now universally recognised, and some special organisation is needed to place it within the reach of the artisan, whose weekly wage, even when he is in good work, does not enable him to defray the expenses of a trained nurse. Sickness in such a family brings in its train many discomforts to the other members, and increased danger to the sufferer; when the father or mother of the family is prostrated by illness, the condition of the household is truly pitiable; it is not merely or chiefly a want of appliances, but a lack of knowledge to appreciate the needs of the invalid, and to make the best use of existing material. Under such circumstances a nurse trained to her duties as a sicktender, and possessed of the special tact which teaches people to help themselves, may work a marvellous change, not only in the surroundings of the invalid, but in the general comfort of the home. That this is no exaggerated statement will be freely admitted by those who have seen what has been done, what is being done day by day, by the agencies which, with limited means, are already at work.

We pointed out, in an article on the work of the Metropolitan and National Nursing Association published some years ago, that a thoroughly wellorganised system of nursing the sick in their own homes might go far towards relieving the hospitals from some of the strain now put upon them. The artisan has been really educated to look upon the hospital as his only resource in serious illness; no alternative has been offered between the skilled nursing and comfortable surroundings of a hospital, and the untrained attentions of well-meaning relatives, generally sufficiently taxed already to meet the ordinary daily round of household duties. Thus it is that, in spite of the separation from friends and relatives which removal to a hospital entails, patients who have once experienced the advantages of skilful nursing are generally anxious again to enjoy them when again suffering from disease. Hospitals are thus often morally forced to admit a large proportion of patients, because it is felt that they cannot be nursed in their own homes, owing to there being no one to organise the willing services of anxious but untrained friends.

The hospital of St. Katharine was founded and richly endowed by Queen Matilda in the year 1148 , and was originally served by the Augustine monks of the neighbouring monastery of the Holy Trinity. The hospital was dedicated by this Queen to St Katharines in pure and perpetual alms, for the repose of the souls of her son Baldwin and her daughter Matilda. Queen Eleanor, widow of Henry III, after a long struggle with the monks, succeeded in regaining control of the hospital for the Crown, and in 1273 founded the hospital afresh for a master, three brother-chaplains, and three sisters, ten poor women called bedeswomen, and six poor scholars; the right to nominate the master, chaplains, and sisters were reserved to herself and the Queens of England, her successors; among subsequent benefactors of the hospital, which appears to have hitherto been a purely religious and charitable institution, we find Edward III and Philippa, his wife, who granted certain lands in Kent and Hertfordshire, and a new charter which specially prescribed visitation of the sick as one of the duties of the community. Richard II, Henry V, Henry VI, Edward IV, and Henry VIII and Queen Katharine, were benefactors of the hospital, which escaped extinction when the other religious houses were suppressed, owing, it is said, to the personal intercession of Anne Boleyn. However this may be, her daughter Queen Elizabeth took some interest in the hospital, and preserved it from destruction. In consequence, we are told, ' of "many heavy complaints made against the Master," Lord Chancellor Somers visited the hospital in 1698, reformed many abuses, and prepared the way for the establishment of a charity school in 1705 . When St. Katharine's Docks were built, the hospital was removed to Regent's Park. The revenues of the hospital, it is provided, may be applied to such good and charitable purposes as may be directed by the royal patroness for the time being.

"The Royal Hospital, of St. Katharine in the Regent's Park, in the County of Middlesex," is at present governed by rules made in July, 1878; the community consists of a Master, three resident brothers, three resident sisters, three extern sisters, ten nurses, ten bedeswomen, and ten bedesmen. There is also a school in which twenty-four girls and thirty-six boys are clothed and taught, and afterwards apprenticed. The only persons directly charged with the duty of tending the sick are the nurses; they are called "the St. Katharine's nurses," and must be connected with societies of bodies for training, superintending, or employing nurses; the stipend paid to each nurse is $£ 50$. There is also a Chapter Clerk, the present incumbent of the office being Sir Arnold White. The Queen is patron and visitor, and the rules appear to provide that almost every question which is likely to arise shall be referred to her; for instance, it is provided that the extern sisters and nurses shall only be appointed to the full number "when the income of the hospital, not otherwise appropriated, in the judgment of the Patron admits." It would not be difficult to graft upon this scheme the new features which would be required to give effect to the Queen's wishes. The buildings for a central office exist in St. Katharine's Hospital, a grey stone edifice well known to persons who traverse the eastern side of Regent's Park; there are resident and non-resident sisters, to whom salaries are paid out of the funds of the hospital, and who may, in process of time, all be required to have had special training in the nursing of the sick.

(British Medical fournal 1888;i:88) 